\title{
On the Intensifier propre ('own') in French: a Counterpart of -même ('-self') in Possessive DPs?
}

\author{
Isabelle Charnavel \\ University of California, Los Angeles
}

\section{Introduction}

French propre (cf. English own, German eigen) exhibits the same readings as -même (cf. English -self, German selbst): like -même, propre presents both the so-called adnominal (e.g. 1) and adverbial (e.g. 2) uses:

a. Paul lui-même va venir.

Paul himself is_going_to come

'Paul himself will come.' (and not only his sister)

b. Dans un moment de folie, Michel a tué ses propres enfants. in a moment of madness Michel has killed his own children 'In a moment of madness, Michel killed his own children.' (and not only the neighbors' children)

b'. the children of Michel himself

c. Dans un moment de folie, Michel a tué ses propres enfants. in a moment of madness Michel has killed his own children 'In a moment of madness, Michel killed his own children.' (and not only the neighbors)

c'. Michel's children themselves

(2) a. Claire a décoré la salle elle-même.

Claire has decorated the room herself

'Claire decorated the room herself.' (without any help)

b. Claire a fabriqué ses propres vêtements.

Claire has made her own clothes

'Claire made her own clothes.' (without any help)

b'. Claire made her clothes herself.

Based on this observation and Eckardt's and Hole's analysis of German selbst, I will argue that propre is a counterpart of -même in possessive DPs. Thus, the goal of this paper is twofold. The main purpose is to show that propre behaves like a flexible intensifier in possessive DPs. I will also suggest that the parallelism between propre and même argues for an unification of the different uses of -même.

I would like to thank Daniel Büring for very useful advice and discussions. 


\section{Intuitions about propre}

First, I describe the intuitions suggesting that propre can have two interpretations: it can contrast either the possessor ${ }^{1}$ (possessor propre) or the possessum (possessum propre) of the possessive DP in which it occurs with a contextually determined set of alternatives.

\subsection{First Case: Possessor propre}

Let's compare the two following sentences:

a. Aujourd'hui, Claire ${ }_{i}$ a pris $\mathrm{sa}_{\mathrm{i}}$ voiture pour aller au travail. today Claire has taken her car for go to_the work 'Today, Claire took her car to go to work.'

b. Aujourd'hui, Claire ${ }_{\mathrm{i}}$ a pris $\mathrm{sa}_{\mathrm{i}}$ propre voiture pour aller au today Claire has taken her own car for go to_the travail. work 'Today, Claire took her own car to go to work.'

Both sentences are true in the same situation where Claire has a car and she took this car to go to work: the presence of propre does not change the truth-conditions of (3b) as compared to (3a).

However, the two sentences do not have the same felicity conditions: (3b) is felicitous only if there is some other referent in the discourse background whose car is or has been under discussion with respect to its use by Claire to go to work. For example, (3b) could be felicitous in the following context: Claire usually takes her husband's car because it works better than hers; but today, she takes her own car instead. Thus, propre requires some other contextually salient referent(s) that play(s) the role of alternative(s).

In other words, propre imposes a contrastiveness condition: an element can be associated with propre only if it is contrasted with other referents that are implicit or explicit in the context. This is further suggested by the fact that propre cannot be used in contexts where a contrast is unfelicitous:

Carole a perdu son (*propre) sang-froid.

Carole has lost her own blood cold

'Carole lost her (*own) cool.'

Since it is impossible that Carole loses someone else's cool, the referent of son ('her'), namely Carole, cannot be contrasted with other alternatives. This precludes the use or propre in (4): propre can only occur in contexts where the generation of contrast-sets of alternatives is possible.

\footnotetext{
${ }^{1}$ Here, I assume as is standard that the relation of possession denotes a broad range of relations. The possessor corresponds to the possessing entity and the possessum to the possessed entity.
} 
Moreover, in this first case - that I call possessor propre -, the alternatives target the possessor. ${ }^{2}$ Thus in (3b), the referent of Claire that is contrasted with other individuals corresponds to the car's possessor: the individual Claire belongs to the set of contextual possible possessors of the car; in particular, the other salient possessor in the context is Claire's husband.

This means that propre has here an effect similar to focusing the possessor by stressing the possessive determiner:

Aujourd'hui, Claire $_{i}$ a pris $\mathbf{S A}_{\mathbf{i}}$ voiture pour aller au travail. today Claire has taken HER car for go to_the work 'Today, Claire took her car to go to work.'

\subsection{Second Case: Possessum propre}

In the first case called possessor propre, the semantic effect of propre consists in contrasting the referent of the possessor with a contextually determined set of alternatives. But we observe a second case in which the alternatives target the possessum, as illustrated by the following example. I call it possessum propre.

a. Arnaud $_{\mathrm{i}}$ est devenu si insupportable que $\mathrm{sa}_{\mathrm{i}}$ fille a cessé de Arnaud is become so unbearable that his daughter has stopped of lui rendre visite.

him visit

'Arnaud has become so unbearable that his daughter stopped visiting him.'

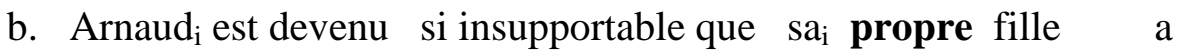
Arnaud is become so unbearable that his own daughter has cessé de lui rendre visite. stopped of him visit 'Arnaud has become so unbearable that his own daughter stopped visiting him.'

As in the case of possessor propre, both sentences are true in the same situation, but they have different felicity conditions: alternatives come into play in (6b). However, it is not the referent of the possessor that is targeted in this sentence. Arnaud - the possessor - is not contrasted with other fathers. Rather, it is Arnaud's daughter - thus the possessum - that is contrasted with other individuals. For example, (6b) would be felicitous in the following context: Arnaud's friend and

\footnotetext{
${ }^{2}$ Note that propre can also target the possessor if it is expressed by a prepositional phrase $d e X$, although it is not judged as good as the other case by all native speakers of French.

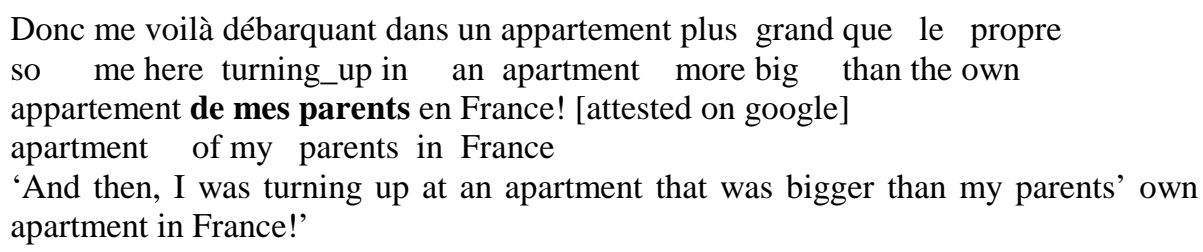


Arnaud's cousin have already stopped visiting Arnaud because he is too bad-tempered. Thus, propre targets the possessum in this case since it is the referent of the whole possessive DP sa fille ('his daughter') that is contrasted with other individuals.

This means that propre has an effect comparable to focusing the possessum by stressing the DP referring to it:
Arnaud $_{i}$ est devenu si insupportable que $\mathrm{sa}_{\mathrm{i}}$ FILle a cessé
Arnaud is become so unbearable that his DAUGHter has stopped de lui rendre visite.
of him visit
'Arnaud has become so unbearable that his daughter stopped visiting him.'

Note that the example (6b) could suggest that it is not the possessum individual, but rather the relation ('daughter') that is contrasted with other relations ('friend' or 'cousin' in the context). But this turns out to be incorrect because it is not necessary that the alternatives be related to the possessor as shown by the following example. The hypothesis that propre targets the relation would predict that the relation of motherhood in (8) is contrasted with other relations. However, at least one of the two alternatives explicitly given in the sentence does not confirm this idea: the witness does not stand in a specific relationship to John that could be a salient alternative to the relation of motherhood. It is rather the individual referring to 'his mother' (the possessum) that is contrasted with the individual referred to as witness. ${ }^{3}$

Ce n' est pas la victime qui a dénoncé $\mathrm{Jean}_{\mathrm{i}}$, ni un témoin, it NE is not the victim who has denounced John nor a witness c' est $\mathrm{sa}_{\mathrm{i}}$ propre mère qui l' a dénoncé!

it is his own mother who him has denounced 'It's not the victim who denounced John, nor a witness, it's his own mother who denounced him!'

\subsection{The Alternatives: Remarks on Existential and Scalar Presuppositions}

Whether propre targets the possessum or the possessor, the alternative propositions may be either true (additive reading) or false (exclusive reading). This means that there is no existential presupposition involved by propre: for example, (8) is felicitous if John's mother is the only individual that denounced John; propre does

\footnotetext{
${ }^{3}$ As in the previous case, the possessum can also be targeted when the possessor is expressed by a prepositional phrase de $X$ : here, the referent of the victim's son is contrasted with other individuals:

(ii) Le meurtrier présumé qui a été placé en hôpital psychiatrique n' est autre the murderer presumed who has been placed in hospital psychiatric NE is other que le propre fils de la victime. [attested on google] than the own son of the victim

'The presumed murderer who has been placed in a psychiatric hospital is no other than the victim's own son.'
} 
not presuppose that any other proposition is true. This is confirmed by the fact that sa propre mère occurs in a cleft; (8) is therefore an example of exclusive reading. But (6b) illustrates that additive readings of possessum propre are possible too: (6b) is felicitous if the alternatives involving Arnaud's friend and Arnaud's cousin are true. Similarly for possessor propre, (3b) does not presuppose that the alternative proposition aujourd'hui, Claire a pris la voiture de son mari pour aller au travail ('today Claire took her husband's car to go to work') is true, and it is actually false in the given context (exclusive reading). Nevertheless, the alternatives do not have to be false either in the case of possessor propre, but may be true (additive reading 4 ) as shown by (9):

(9) Louis i $_{\mathrm{i}}$ oublie toujours les anniversaires des gens. En fait, il a Louis forgets always the birthdays of people. in fact he has récemment oublié son propre anniversaire! recently forgotten his own birthday 'Louis always forgets people's birthdays. Actually, he recently forgot his own birthday!'

So neither possessor propre nor possessum propre involves any existential presupposition. Propre is different from the focus particle even in this respect, since even presupposes that the proposition is true for at least one other element in the focus-generated set of alternatives.

However, just like even, possessum propre seems to involve a scalar presupposition, which orders the focus alternatives on a scale of expectedness. In every example involving possessum propre, the individual targeted by propre is an unlikely one 5 in the context. That's why the following sentence is comparable to (6b): the only difference is that there is an existential presupposition here but not in (6b):

Arnaud $_{\mathrm{i}}$ est devenu si insupportable que même sa fille a Arnaud is become so unbearable that even his daughter has cessé de lui rendre visite. stopped of him visit 'Arnaud has become so unbearable that even his daughter stopped visiting him.'

\footnotetext{
${ }^{4}$ The terms additive and exclusive have been proposed in the literature about German selbst ('-self') to differentiate two kinds of readings: in the first case, the alternatives are true, while they are false in the second case. See Eckardt (2001: 392) for more details.

${ }^{5}$ In the case of scalar presupposition, it is usually assumed that the target proposition is the least likely of all the alternative propositions (concerning such a scalar presupposition for even, cf. for example Rullmann 1997). But at least for propre, it does not seem to be correct to claim in (6b) that another individual such as Arnaud's mother cannot be as unlikely as Arnaud's daughter to stop visiting him, and the sentence would still be felicitous if Arnaud's mother is salient in the context too. That's why I propose that the individual targeted by propre is not the least likely one, but an unlikely one. In other words, the likelihood scale does not have a total order, but only a partial one.
} 
However, possessor propre does not yield such scalar presupposition: in (3b), Claire is not less expected than her husband to be the possessor of the car that she takes to go to work.

So unlike possessor propre, possessum propre presents the same scalar presupposition as even; but like possessor propre, it does not involve the existential presupposition that even involves.

To sum up the semantic intuitions about propre, it appears that propre does not change the truth-conditions of the sentence in which it appears, but its felicity conditions: the semantic contribution of propre consists in contrasting the possessor or the possessum of the possessive DP in which it occurs with a contextually determined set of alternatives. These alternatives may be true or false, and they are ordered on a scale of likelihood only in the case of possessum propre.

\section{Formalization: propre as a Flexible Intensifier Counterpart of -même in Possessive DPs}

The main semantic intuitions about propre are similar in several respects to the intuitions that have been reported for German selbst ('-self'; cf. French -même) referred to as an intensifier. So, based on the analysis that has been proposed for selbst, I will argue that propre is a counterpart of the intensifier -même 6 in possessive DPs and that propre therefore falls into the class of intensifiers.

\subsection{Analysis of German Adnominal selbst (Eckardt 2001, Hole 2002)}

Let's compare these two sentences to determine the semantic import of adnominal selbst:

a. Der König selbst wird teilnehmen.

the king himself will attend

'The king himself will attend.'

b. Der König wird teilnehmen.

the king will attend

'The king will attend.'

Both sentences are true in a situation where the king will come to the meeting under discussion. So like propre, selbst does not change the truth-conditions of (11a) as compared to (11b).

But in (11a), at least one other person is under discussion as a possible attendee. For example, the sentence is felicitous in a context where the ministers usually attend the kind of meeting that is under discussion, but not the king; however, this time, the king will come in person. Therefore, selbst involves

\footnotetext{
${ }^{6} \mathrm{I}$ assume here that the analysis provided for German selbst can be adapted to French -même.
} 
alternatives to the referent of the DP to which it adjoins, namely here, alternatives to the referent of the king.

To capture these intuitions, it has been proposed that selbst is an identity function under focus.

First, since selbst does not change the truth-conditions of the sentence, it is assumed to denote the identity function over individuals. (12) presents Eckardt's proposal for the lexical entry of selbst. ${ }^{7}$

$$
\begin{aligned}
& \text { ID: } D_{e} \rightarrow D_{e} \\
& I D(a)=\text { a for all } a \in D_{e} \quad(\text { cf. Eckardt 2001: 380) }
\end{aligned}
$$

Adnominal selbst is thus a function of type $\langle\mathrm{e}, \mathrm{e}\rangle$ which maps individuals to themselves. ${ }^{8}$

So far, this predicts that selbst is a purely vacuous element. But crucially, the focus accent that is typically observed on selbst leads to a Rooth-style focus meaning of selbst (cf. Rooth 1985, 1992): selbst, which does not make a difference in the ordinary denotation, makes a crucial difference in the focus meaning by introducing alternative functions on the domain of individuals. The focus meaning of selbst is the set of all functions which map individuals to other individuals.

$$
\begin{aligned}
& \text { Ordinary meaning } \\
& \llbracket \text { selbst } \rrbracket^{\circ}=\lambda \mathrm{x}_{\mathrm{e}} . \mathrm{X}
\end{aligned}
$$

Focus meaning $\llbracket$ selbst $\rrbracket^{\mathrm{f}}=\left\{\mathrm{f}_{<\mathrm{e}, \mathrm{e}\rangle}: \mathrm{f}(\mathrm{x}) \neq \mathrm{x}\right\}^{9}$ $=\left\{\lambda x_{e}\right.$. the $y$ such that $y$ is $x$ 's minister, $\lambda x_{e}$. the $y$ such that $y$ is $x$ 's wife, $\lambda x_{e}$. the $y$ such that $y$ is $x$ 's proxy...

Thus, selbst evokes alternative functions on the domain of individuals and therefore, it indirectly induces a set of alternative individuals. This presumably predicts the so-called centrality effects: ${ }^{10}$ the set of functions alternative to the identity function will induce a set of alternative individuals structured into a center held by the referent of the DP to which selbst adjoins, and the alternative functions denote relationships between the central individual and the alternative individuals.

\footnotetext{
${ }^{7}$ This kind of denotation was already proposed in Moravcsik (1972) who argues that intensifying selbst denotes the identity function ID on the domain of objects.

${ }^{8}$ This correctly predicts that selbst adjoins to proper names and definite DPs. Moreover, Eckardt (2001: 380) also provides a type-lifted version of (12), which can be used under analyses which assume a generalized-quantifier account for plural DPs and in the case of specific indefinites as well.

${ }^{9}$ This is the formulation proposed by Hole (2002), who purposefully chooses not to include the identity function in the set of alternatives even if strictly speaking, a p-set à la Rooth has the focused element in it.

${ }^{10}$ The centrality effects on the alternatives to DP-selbst have received close attention in the literature. In (11a) for instance, the king is perceived as the central figure in the government and is central in the contextually given alternatives.
} 
Note that contextual information, the knowledge state of the interlocutors and other factors constrain the set of relevant alternatives.

Based on this analysis and the similar intuitions observed in the case of selbst and propre, I propose that propre also falls into the class of intensifiers, defined as elements that involve an identity function under focus. ${ }^{11}$ This will capture the intuitions that propre does not change the truth-conditions, but only the felicity conditions of the sentence.

\subsection{The Meanings of propre}

\subsubsection{Differences between selbst and propre}

However, this cannot be the whole story: propre cannot simply denote the identity function under focus, since it exhibits specific properties due to its distribution restricted to possessive DPs.

First, propre does not present the same combinatorial possibilities as selbst. Propre only occurs in definite possessive DPs that express both the possessor and the possessum. As illustrated by the following examples, propre is ungrammatical if the possessor or the possessum is not expressed (cf. 14-15) and if it combines with indefinites or quantifiers (cf. 16-17).

$$
\begin{aligned}
& \text { *le propre chien } \\
& \text { the own dog } \\
& \text { * propre Jean } \\
& \text { own John } \\
& \text { * un propre chien de Jean } \\
& \text { a own dog of John } \\
& \text { * quelques propres chiens de Jean } \\
& \text { some own dogs of John }
\end{aligned}
$$

Therefore, propre cannot simply denote the identity function since this would incorrectly predict that propre can combine with proper names and definite descriptions, as illustrated by the ungrammaticality of (14)-(15).

Moreover, as opposed to selbst, propre is a flexible intensifier: even if it only appears in one specific syntactic position, namely in the prenominal position of possessive DPs, we have seen that it can have two targets for intensification, the

\footnotetext{
${ }^{11}$ Even if both intensifiers such as selbst ('-self') and focus particles such as even or only involve focus effects, Eckardt argues that intensifiers such as selbst represent a class distinct from the class of focus particles for several reasons (cf. Eckardt 2001: 403): in particular, as opposed to selbst ('even'), selbst ('self') has adnominal sortal restrictions; it is stressed; there is no accent on the associated element; centrality effects arise; both additive and exclusive uses are possible; it syntactically follows the associated element.
} 
possessor and the possessum. On the other hand, selbst can only intensify the DP that it adjoins to: this means that selbst is not a flexible intensifier, but it always has the same target for intensification when appearing in a certain syntactic position. Moreover, selbst does not occupy a fixed syntactic position: it can be adnominal or adverbial. ${ }^{12}$ Thus, propre appears in a fixed syntactic position but is a flexible intensifier, whereas selbst occurs in a flexible syntactic position but is a fixed intensifier.

Therefore, to capture these differences between selbst and propre without obscuring their similarity as intensifiers, I argue that propre is a type-lifted variant of the identity function in focus, i.e. a type-lifted variant of selbst (or French - même) with two different targets for the identity function. This reflects the idea that propre is an intensifier similar to -même, except that it is specialized in possessive DPs, which accounts for its specificities.

\subsubsection{The Ordinary Meaning of propre}

I propose that the right analysis can be derived if we formulate the two following ordinary meanings for possessor propre and possessum propre:

(18) $\llbracket$ possessor propre $\rrbracket^{\circ}=\lambda \mathrm{R} \cdot \lambda \mathrm{x} \cdot \lambda \mathrm{a} \cdot \mathrm{a}(\mathrm{R}(\mathrm{ID}(\mathrm{x})))$

(19) $\llbracket$ possessum propre $\rrbracket^{\circ}=\lambda \mathrm{R} . \lambda \mathrm{x} . \lambda \mathrm{a}$. ID $(\mathrm{a}(\mathrm{R}(\mathrm{x})))$

i. $I D$ is the identity function on the domain of individuals: $\langle\mathrm{e}, \mathrm{e}\rangle$

ii. $R$ is a variable over possessive relations: <e, et>

iii. $x$ is a variable over individuals: 〈e>

iv. $a$ is a specific kind of choice function defined for singleton sets: <et, e>

These denotations capture three main aspects of propre: (a) its distribution in definite possessive DPs (b) its vacuous meaning with respect to truth-conditions and (c) its flexibility in intensification.

(a) First, these denotations predict the right distribution for propre: it has to combine with a possessive relation ( $\mathrm{R}$, which is commonly expressed by a relational noun), a possessor individual (x), and it is only compatible with definite articles, as opposed to indefinite articles or quantifiers, as predicted by $a$, which corresponds to the definite article (cf. THE $=\lambda \mathrm{P} . \mathrm{xP}(\mathrm{x})$ ).

(b) Moreover, this ordinary meaning is vacuous with respect to the truth-conditions since neither the identity function nor the simple combination of

\footnotetext{
${ }^{12}$ Selbst occupies an adverbial position in cases such as:

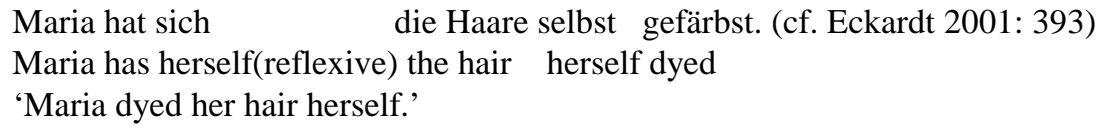

I will come back to the meaning of adverbial selbst, but the point here is that there is only one reading in this case; therefore, there is only one intensifying possibility per syntactic position in the case of selbst as opposed to propre.
} 
the possessive relation, the individual and the definite article can yield a semantic effect in the narrow sense. Thus, this correctly predicts that la propre mère de Jean ('John's own mother') has the same ordinary meaning as la mère de Jean ('John's mother'), as illustrated in (24). This is the case whether we deal with possessor propre or possessum propre, since the fact that the identity function takes different arguments in both cases does not make any difference in the ordinary meaning. ${ }^{13}$

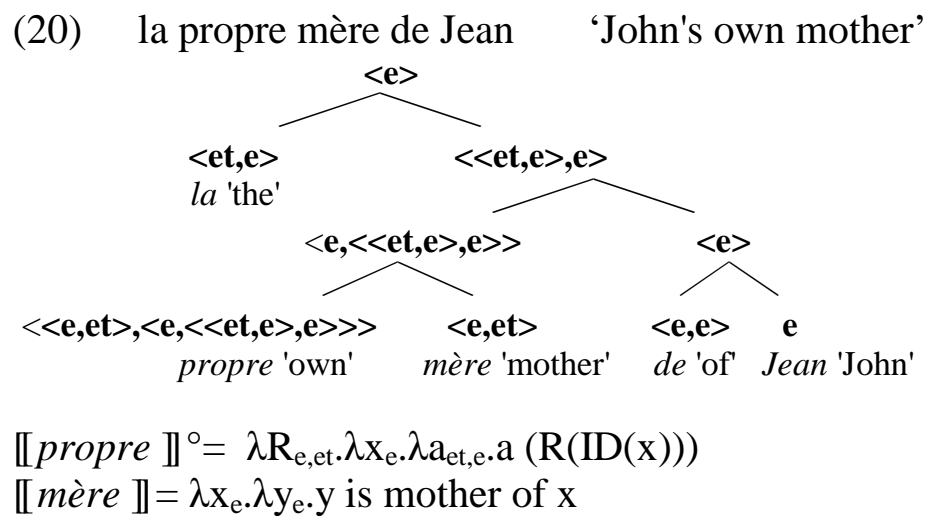

\footnotetext{
${ }^{13}$ Note that in the case of non relational nouns, I suppose as is standard the presence of an abstract $\operatorname{POSS}\left(\lambda \mathrm{f}_{\mathrm{et}} \cdot \lambda \mathrm{x}_{\mathrm{e}} \cdot \lambda \mathrm{y}_{\mathrm{e}} \cdot \mathrm{f}(\mathrm{y})=1\right.$ and $\mathrm{y}$ is possessed by $\left.\mathrm{x}\right)$.

Moreover, in the case of the possessive determiner son ('his'), I assume that son is decomposed into le 'the' and de lui ('of him'). These two points are exemplified here:
}

sa propre voiture

'his own car'

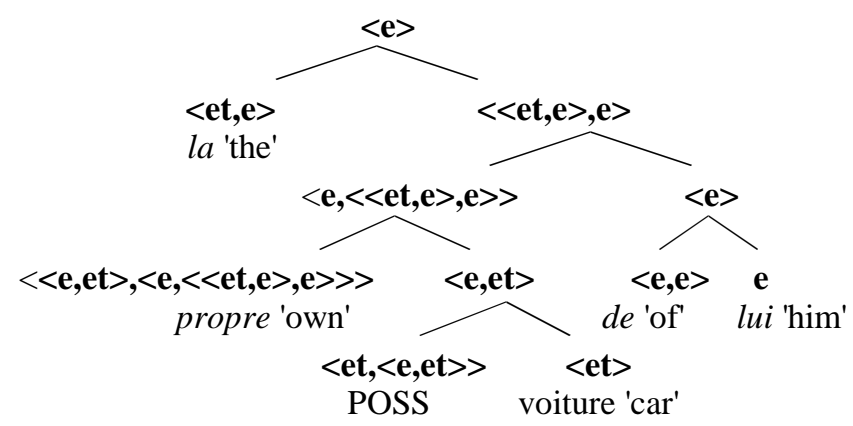

《voiture $\rrbracket=\lambda \mathrm{x}_{\mathrm{e}} \cdot \mathrm{x}$ is a car

$\llbracket P O S S \rrbracket=\lambda \mathrm{f}_{\mathrm{et}} \cdot \lambda \mathrm{x}_{\mathrm{e}} \cdot \lambda \mathrm{y}_{\mathrm{e}} \cdot \mathrm{f}(\mathrm{y})=1$ and $\mathrm{y}$ is possessed by $\mathrm{x}$

$\llbracket P O S S$ voiture $\rrbracket=\lambda \mathrm{x}_{\mathrm{e}} \cdot \lambda \mathrm{y}_{\mathrm{e}} \cdot \mathrm{y}$ is a car and $\mathrm{y}$ is possessed by $\mathrm{x}$

[propre $\rrbracket^{\circ}=\lambda \mathrm{R}_{\mathrm{e}, \mathrm{e}} \cdot \lambda \mathrm{x}_{\mathrm{e}} \cdot \lambda \mathrm{a}_{\mathrm{et}, \mathrm{e}} \cdot \mathrm{a}(\mathrm{R}(\mathrm{ID}(\mathrm{x})))$

$\llbracket$ propre POSS voiture $\rrbracket^{\circ}=\lambda \mathrm{x}_{\mathrm{e}} \cdot \lambda \mathrm{a}_{\mathrm{et}, \mathrm{e}} \cdot \mathrm{a}\left(\left[\lambda \mathrm{x}_{\mathrm{e}} \cdot \lambda \mathrm{y}_{\mathrm{e}} \cdot \mathrm{y}\right.\right.$ is a car and $\mathrm{y}$ is possessed by $\left.\left.\mathrm{x}\right](\mathrm{ID}(\mathrm{x}))\right)$

$\llbracket d e \rrbracket=\lambda \mathrm{x}_{\mathrm{e}} \cdot \mathrm{x}$

$\llbracket l u i \rrbracket=\llbracket$ de lui $\rrbracket=$ John

【propre POSS voiture de lui $\rrbracket^{\circ}=\lambda \mathrm{a}_{\mathrm{et}, \mathrm{e}} \cdot \mathrm{a}\left(\left[\lambda \mathrm{x}_{\mathrm{e}} \cdot \lambda \mathrm{y}_{\mathrm{e}} \cdot \mathrm{y}\right.\right.$ is a car and $\mathrm{y}$ is possessed by $\left.\left.\mathrm{x}\right](\operatorname{ID}(\mathrm{John}))\right)$

$=\lambda \mathrm{a}_{\mathrm{et}, \mathrm{e}} \cdot \mathrm{a}\left(\lambda \mathrm{y}_{\mathrm{e}} \cdot \mathrm{y}\right.$ is a car and $\mathrm{y}$ is possessed by John)

$\llbracket l a \rrbracket=\lambda \mathrm{f}_{\text {et; }}$ and there is exactly one $\mathrm{x}$ such that $\mathrm{f}(\mathrm{x})=1$. the unique $\mathrm{y}$ such that $\mathrm{f}(\mathrm{y})=1$

$\llbracket$ la propre POSS voiture de lui $\rrbracket^{\circ}=$ the unique $\mathrm{y}$ such that $\left[\lambda \mathrm{y}_{\mathrm{e}} . \mathrm{y}\right.$ is a car and $\mathrm{y}$ is possessed by $\operatorname{John}](\mathrm{y})=1$

$=$ the unique $\mathrm{y}$ such that $\mathrm{y}$ is a car and $\mathrm{y}$ is possessed by John 
【propre mère $\rrbracket^{\circ}=\lambda \mathrm{x}_{\mathrm{e}} \cdot \lambda \mathrm{a}_{\mathrm{et}, \mathrm{e}} \mathrm{a}\left(\left[\lambda \mathrm{x}_{\mathrm{e}} \cdot \lambda \mathrm{y}_{\mathrm{e}} \mathrm{y}\right.\right.$ is mother of $\left.\left.\mathrm{x}\right](\operatorname{ID}(\mathrm{x}))\right)$

$\llbracket d e \rrbracket=\lambda \mathrm{x}_{\mathrm{e}} \cdot \mathrm{x}$

$\llbracket$ Jean $\rrbracket=\llbracket$ de Jean $\rrbracket=$ John

$\llbracket$ propre mère de Jean $\rrbracket^{\circ}=\lambda \mathrm{a}_{\mathrm{et}, \mathrm{e}} \cdot \mathrm{a}\left(\left[\lambda \mathrm{x}_{\mathrm{e}} \cdot \lambda \mathrm{y}_{\mathrm{e}} \mathrm{y}\right.\right.$ is mother of $\left.\left.\mathrm{x}\right](\operatorname{ID}(\mathrm{John}))\right)$

$=\lambda \mathrm{a}_{\mathrm{et}, \mathrm{e}} \mathrm{a}\left(\lambda \mathrm{y}_{\mathrm{e}} \mathrm{y}\right.$ is mother of John)

$\llbracket l a \rrbracket=\lambda \mathrm{f}_{\text {et; }}$ and there is exactly one $\mathrm{x}$ such that $\mathrm{f}(\mathrm{x})=1$. the unique $\mathrm{y}$ such that $\mathrm{f}(\mathrm{y})=1$

[la propre mère de Jean $\rrbracket^{\circ}=$ the unique $\mathrm{y}$ such that $\left[\lambda \mathrm{y}_{\mathrm{e}} \mathrm{y}\right.$ is mother of John $](\mathrm{y})=1$

$=$ the unique $\mathrm{y}$ such that $\mathrm{y}$ is mother of John

(c) Thus, the denotation for the ordinary meaning of propre expresses the vacuity of propre with respect to the truth-conditions. However, it crucially predicts a difference in the focus meaning of possessor propre and possessum propre: since the identity function takes two different arguments (possessor (x) or possessum $(\mathrm{a}(\mathrm{R}(\mathrm{x}))))$, two different contrast-sets of alternatives are involved. In other words, this scope difference of the identity function predicts the flexibility in intensification of propre. This will be made clearer by examining the focus meaning of propre.

\subsubsection{The Focus Meaning of propre}

Like selbst, propre is stressed and this is the case for both possessor and possessum propre. ${ }^{14}$ This empirical observation suggests that propre is in focus, and this will predict the effect of propre on the felicity conditions of the sentence. While propre does not contribute anything to the meaning of the sentence, it will become meaningful if it is in focus: focused propre will, like any other focused item, evoke focus alternatives that will enter in the meaning of the respective focus construction.

Therefore, I propose that propre has a focus meaning à la Rooth (1985, 1992): the focus meaning of an item in focus is the set of all type-identical alternatives to it. However, the case of propre is a little more specific: since propre denotes a type-lifted variant of the identity function, I assume that the focus alternatives of propre are type-lifted variants of other functions from $D_{e}$ to $D_{e}{ }^{15}$ as shown in (26): propre in focus relates to alternative functions on the domain of individuals.

(21) $\llbracket$ propre $\|^{\mathrm{f}}=\left\{\mathrm{Lift}_{\mathrm{n}}(\mathrm{f}) \mid \mathrm{f}\right.$ is a contextually salient alternative to ID $\}$ for appropriate lifts $\mathrm{Lift}_{1}-\mathrm{Lift}_{2}$

To this end, two lifts are necessary depending on which argument the identity function takes (the possessor or the possessum) as illustrated in (22) and (23).

\footnotetext{
${ }^{14}$ This is at least the case in my dialect of French. Note however that this seems to be different for German eigen or English own according to several German and English speakers: in these two cases, possessor propre is stressed whereas possessum propre is not, but the possessee is.

a) possessor own: his OWN daughter (cf. German: seine EIgene Tochter)

b) possessum own: his own DAUghter (cf. German: seine eigene TOCHter)

${ }^{15}$ I adopt here the same strategy as Eckardt, who proposes type-lifted variants of the identity function for adverbial selbst (2001: 381).
} 
possessor propre
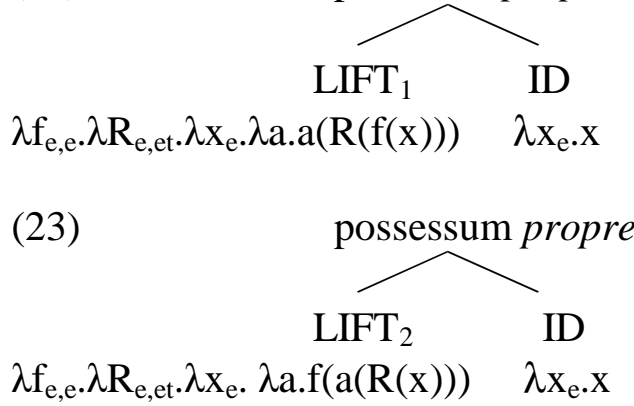

Thus, since focus on propre generates alternative functions on the domain of individuals, I predict that focused propre indirectly induces a set of alternative individuals in $\mathrm{D}_{\mathrm{e}}$, as shown in (24).

(24) Let $a$ be the referent of the element intensified by propre. Let $\left\{\mathrm{f}_{1}, \mathrm{f}_{2}, \mathrm{f}_{3}, \ldots \mathrm{f}_{\mathrm{k}}\right\}$ be salient alternatives to ID in the given context $\mathrm{C}$. Here is the induced set of alternatives to a in $\mathrm{D}_{\mathrm{e}}{ }^{16}$ in context $\mathrm{C}$ :

$\operatorname{Alt}(C)(a)=\left\{f_{1}(a), f_{2}(a), f_{3}(a) \ldots f_{k}(a)\right\}$

Note that it is the context that restricts the potentially infinite set of individuals to the salient alternatives relevant in the discourse situation. Also, this analysis does not say anything about the truth of the alternatives, which correctly predicts that alternative propositions to the sentence including focused propre may be true (additive reading; cf. 6b, 9) or false (exclusive reading; cf. 3b, 8).

Let's apply this analysis to example (3b) repeated here:

(25) $[=3 \mathrm{~b}]$ Aujourd'hui, Claire ${ }_{i}$ a pris $\mathrm{sa}_{\mathrm{i}}$ propre voiture pour aller au today Claire has taken her own car for go to_the travail. work 'Today, Claire took her own car to go to work.'

As shown above, this is an example of possessor propre since Claire is contrasted with another possessor of the car, namely her husband in the context: instead of taking her husband's car, Claire takes her own car today. Thus, the ordinary meaning of propre is the following one, where the identity function takes the possessor individual as argument:

$$
\llbracket \text { propre } \rrbracket^{\circ}=\lambda \mathrm{R} . \lambda \mathrm{x} \cdot \lambda \mathrm{a} \cdot \mathrm{a}(\mathrm{R}(\mathrm{ID}(\mathrm{x})))
$$

Therefore, the focus meaning of propre in this sentence is the set of type-lifted variants (using Lift $_{1}$ ) of contextually salient alternative functions to the identity

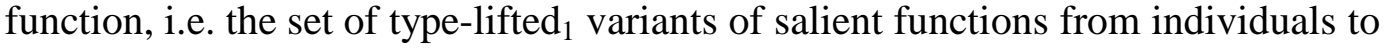
individuals except for the identity function. Since the relevant alternative possessor

\footnotetext{
${ }^{16}$ I borrow this name from Eckardt (2001: 382).
} 
of the car in the context is Claire's husband, there is only one contextually salient alternative function to the identity function, namely the function that takes Claire as argument and returns her husband; for obvious reasons, I call this function HUSBAND-OF.

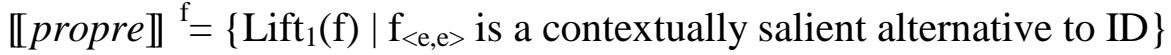

$$
\begin{aligned}
& \left.\mathrm{f}_{\langle\mathrm{e}, \mathrm{e}}\right\rangle \in\{\text { HUSBAND-OF }\}
\end{aligned}
$$

Therefore, the induced set of alternatives to Claire in the domain of individuals is as follows:

Alt $(C)($ Claire $)=\{$ HUSBAND-OF $($ Claire $)\}$

Thus, the focus semantic value of (25) is the following set of propositions:

[ A Aujourd'hui, Claire a pris sa [propre] ${ }_{\mathrm{F}}$ voiture pour aller au travail $\rrbracket^{\mathrm{f}}=$ $\{$ today, Claire took x's car to go to work/ $x \in \operatorname{Alt}(\mathrm{C})($ Claire $)\}$

This correctly means that the focus semantic meaning of the sentence 'today, Claire took her own car to go to work' is the alternative proposition 'today, Claire took her husband's car to go to work.'

\subsubsection{Organization of the Alternatives: Remarks on Centrality and Scalarity}

So far, I have argued that the core meaning of propre consists in involving a set of alternative functions to ID, which indirectly derives a set of alternative individuals to the possessor or the possessum. Thus, the alternatives play a crucial role in the meaning of propre; that's why I want to clarify the structuration of these alternatives. I have already mentioned that the potentially infinite number of alternatives is restricted by the context and the alternatives may be true or false. Now, the question is how the alternatives are organized.

First, the question of the so-called centrality effect arises given that it has received close attention in the literature about selbst. There is however an empirical difference between selbst and propre in this respect: in the case of propre (possessor propre or possessum propre), we observe that the alternative individuals need not be related to the individual intensified by propre, as illustrated by the following examples:

(26) Michel déteste louer des voitures, il préfère conduire sa propre voiture. Michel hates rent some cars he prefers drive his own car 'Michel hates renting cars, he prefers driving his own car.'

(27) [=8] Ce n' est pas la victime qui a dénoncé $\mathrm{Jean}_{\mathrm{i}}$, ni un témoin, it NE is not the victim who has denounced John nor a witness c'est $\mathrm{sa}_{\text {i }}$ propre mère qui l' a dénoncé!

it is his own mother who him has denounced 'It's not the victim who denounced John, nor a witness, it's his own mother who denounced him!'

In (26), Michel is implicitly contrasted with rental car companies as possessors of the car (possessor propre). But Michel does not have any privileged relation to this kind of company that could identify the alternative function taking Michel as 
argument and returning a rental car company: Michel is not central with respect to the possessors of rental cars. Similarly in (27), which is a case of possessum propre, the alternatives (the witness in particular) are not specifically related to the possessum John's mother: the possessum is not central with respect to the victim or the witness.

The absence of centrality effects for propre is therefore an empirical difference between selbst and propre; but this does not affect the analysis proposed here. Indeed, it does not necessarly predict that the alternative possessors are related to the intensified one. The alternative functions do not logically have to express human relationships, but logically speaking, we can find for any set $\left\{a, a_{1}, \ldots, a_{k}\right\}$ on $D_{e}$ a set of functions $\left\{f_{1}, f_{2}, f_{3} \ldots f_{k}\right\}$ such that $f_{1}(a)=a_{1}, f_{2}(a)=a_{2} \ldots, f_{k}(a)=a_{k}$. Any alternative individual can be returned by any alternative function to the identity function.

Thus, the alternative individuals indirectly induced by propre -unlike selbst- are not structured into a center. However, they are ordered on a scale of likelihood in the case of possessum propre: as opposed to selbst $t^{17}$ and possessor propre, ${ }^{18}$ possessum propre induces a scalarity effect. As shown above, the proposition containing the intensified element is an unlikely one as compared to the alternative propositions. For example in (6b) (repeated below), Arnaud's daughter is an unlikely individual to stop visiting Arnaud among the contextual alternatives Arnaud's cousin and Arnaud's friend.

(28) [=6b] Arnaud est devenu si insupportable que sa propre fille a

Arnaud is become so unbearable that his own daughter has cessé de lui rendre visite

stopped of him visit

'Arnaud has become so unbearable that his own daughter stopped visiting him.'

This is the same kind of scalarity effect as the one induced by the focus sensitive particle même (cf. 10). But as mentioned above, the difference consists in the absence of an existential presupposition in the case of propre.

To account for this scalarity effect, I propose that possessum propre is associated with a silent element even that triggers a scalar presupposition. This is

\footnotetext{
${ }^{17}$ Eckardt (2001: 376) specifies that "not all examples of stressed selbst evoke a scale of surprise", as exemplified by the following sentence:

(iv) Der Busfährer selbst erlitt einen Schädelbruch. the bus driver himself suffered a fracture of the skull 'The bus driver himself suffered a fracture of the skull.'

${ }^{18}$ The following example shows that possessor propre does not involve any scalarity effect: it is not surprising that Benjamin prefers sleeping in his own bed as opposed to other people's beds.

Benjamin préfère dormir dans son propre lit.

Benjamin prefers sleep in his own bed

'Benjamin prefers sleeping in his own bed.'
} 
probably related to the possibly hidden even involved by minimizers (cf. Heim 1984) that denote the low endpoint of the contextually relevant pragmatic scale as illustrated in (29):

$$
\text { He didn't }<\text { EVEN > lift a finger. }
$$

Hidden even introduces here a scalar presupposition: the proposition is the least likely proposition among the set of alternative propositions.

Let's apply this analysis to example (6b) repeated here:

[=6b] Arnaud est devenu si insupportable que $\langle$ EVEN $>$ sa [propre] fille Arnaud is become so unbearable that his own daughter a cessé de lui rendre visite. has stopped of him visit 'Arnaud has become so unbearable that his own daughter stopped visiting him.'

As shown above, this is an example of possessum propre since Arnaud's daughter is contrasted with other individuals, namely Arnaud's cousin and Arnaud's friend in the context. Thus, the ordinary meaning of propre is the following one, where the identity function takes the possessum individual as argument:

[I possessum propre $\rrbracket^{\circ}=\lambda \mathrm{R} \cdot \lambda \mathrm{x} \cdot \lambda \mathrm{a} \cdot \mathrm{ID}(\mathrm{a}(\mathrm{R}(\mathrm{x})))$

Therefore, the focus meaning of propre in this sentence is the set of type-lifted variants (using $\mathrm{Lift}_{2}$ ) of contextually salient alternative functions to the identity

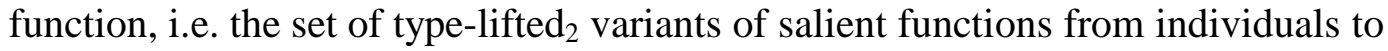
individuals except for the identity function. Since the relevant alternative possessees in the context are Arnaud's cousin and Arnaud's friend, there are two contextually salient alternative functions to the identity function: the function $\mathrm{g}_{1}$ that takes Arnaud's daughter as argument and returns Arnaud's cousin and the function $\mathrm{g}_{2}$ that takes Arnaud's daughter as argument and returns Arnaud's friend.

[I propre $]]^{\mathrm{f}}=\left\{\operatorname{Lift}_{2}(\mathrm{f}) \mid \mathrm{f}_{<\mathrm{e}, \mathrm{e}\rangle}\right.$ is a contextually salient alternative to ID $\}$ $\mathrm{f}_{<\mathrm{e}, \mathrm{e}} \in\left\{\mathrm{g}_{1} ; \mathrm{g}_{2}\right\}$

Therefore, the induced set of alternatives to Arnaud's daughter in the domain of individuals is as follows:

Alt $(\mathrm{C})$ (Arnaud's daughter) $=\left\{\mathrm{g}_{1}\right.$ (Arnaud's daughter); $\mathrm{g}_{2}$ (Arnaud's daughter) $\}$

$=\{$ Arnaud's cousin; Arnaud's friend $\}$

Thus, the focus semantic value of (30) is the following set of propositions, on which even operates:

[IArnaud est devenu si insupportable que $<$ EVEN $>$ sa $[\text { propre }]_{F}$ fille a cessé de lui rendre visite $]]^{\mathrm{f}}=\{$ Arnaud has become so unbearable that $\mathrm{x}$ stopped visiting him/ $x \in \operatorname{Alt}(\mathrm{C})$ (Arnaud's daughter)

This correctly means that the focus semantic meaning of the sentence $\mathrm{p}$ 'Arnaud has become so unbearable that his daughter stopped visiting him' is the set of the alternative propositions $\mathrm{p}_{1}$ 'Arnaud has become so unbearable that his cousin stopped visiting him' and $\mathrm{p}_{2}$ 'Arnaud has become so unbearable that his friend 
stopped visiting him'. Moreover, silent $\langle$ EVEN $\rangle$ introduces the presupposition that $\mathrm{p}$ is least likely than $\mathrm{p}_{1}$ and $\mathrm{p}_{2}$.

To sum up, the alternatives involved in the case of propre are not structured into a center, but silent even associated with possessum propre induces their ordering on a scale of likelihood.

Despite these differences concerning the alternatives, I have thus argued that propre is a counterpart of -même in possessive DPs. Like -même, propre is an intensifier, and its specificities come from its restricted distribution in possessive DPs: it is a flexible intensifier in that it can intensify either the possessor or the possessum.

\subsection{Agentive propre}

The spirit of this analysis that treats -même (corresponding to German selbst) and propre in a similar way is further justified by another empirical observation: propre seems to present the same variety of readings as selbst. In particular, selbst arguably exhibits two different readings depending on its syntactic position: adnominal selbst - that I have been referring to so far - differs from adverbial selbst that presents an agentive reading. The two following examples borrowed from Hole (2002) illustrate the difference. Moreover, the corresponding French examples show that the same difference holds for French -même:

Paul selbst wird teilnehmen, nicht nur seine Schwester. (adnominal use) Paul himself will attend, not only his sister. 'Paul himself will attend, not just his sister.'

cf. French: Paul lui-même va venir, et pas seulement sa sœur.

Paul will selbst aufräumen. (adverbial-agentive use)

Paul wants himself clean_up

'Paul wants to clean up himself.' (= without any help)

cf. French: Paul veut ranger lui-même.

In (31), adnominal selbst says that at least one other person is under discussion as a possible attendee; in (32), agentive selbst expresses the idea that Paul does not delegate the job of cleaning up. To formalize these intuitions, Hole (2002) argues that in the case of adnominal selbst, the focused identity function takes as argument the DP to which selbst adjoins; but in the case of agentive selbst, it takes the agentive Voice Head proposed by Kratzer (1996). ${ }^{19}$

The important point for our purposes is that both readings are available with propre as well. Whereas possessor and possessum propre correspond to adnominal même (-même adjoined to the possessor or the possessum), ${ }^{20}$ the following

\footnotetext{
${ }^{19}$ See Hole (2002) for more details about his analysis of agentive selbst.

${ }^{20}$ Thus in (3b), sa propre voiture ('his own car') roughly corresponds to la voiture de Claire elle-même ('the car of Claire herself') and in (6b), sa propre fille ('his own daughter') roughly corresponds to sa fille elle-même ('his daughter herself').
} 
examples illustrate two cases of agentive propre. This reading is particularly salient with deverbal nouns (33a) and objects of creation verbs (34a).

a. Ce site internet est de sa propre création.

this site internet is of his own creation

'This website is his own creation.'

b. Cyril a créé ce site internet lui-même.

Cyril has created this site internet himself

'Cyril created this website himself.' [= without help]

a. Claire a fabriqué ses propres vêtements.

Claire has made her own clothes

'Claire made her own clothes.'

b. Claire a fabriqué ses vêtements elle-même.

Claire has made her clothes herself

'Claire made her clothes herself.' [= without help]

Indeed, (33a) can be paraphrased by (33b) that clearly involves agentive -même. So, both sentences express the idea that Cyril created the website without any help. They do not mean that Cyril as opposed to someone else created the website, but Cyril is in an agentive relation to the creation of the website (as opposed to other alternative relations). Similarly, both (34a) and its paraphrase (34b) say that Claire made her clothes without any help. Under this reading, (34a) does not mean that Claire made her clothes as opposed to someone else's clothes (as possessor propre would predict) or as opposed to something else (as possessum propre would predict), but that she made them by herself, without any help.

This observation would require further investigation, in particular to understand why such readings are particularly salient when propre is associated with deverbal nouns or creation verbs, and to provide an exact analysis of such readings. But for my purposes, it is enough for now to notice that propre presents the same range of readings as même. This argues in favor of the idea exposed here that propre and -même fall into the same class. Moreover, this suggests that adnominal and adverbial -même should not be analyzed as two different phenomena as it has often been proposed: 21 it is presumably not accidental that these two readings arise together with two different morphological roots (-même and propre). Therefore, this argues for an unification of -même and this supports Hole's hypothesis that unifies the two uses of selbst: according to his hypothesis, the only difference between adnominal and adverbial selbst is the argument that the identity function takes (DP or agentive Voice Head).

\section{Conclusion}

In this paper, I have proposed that French propre is an intensifier that is restricted to possessive DPs: in this sense, propre is the counterpart of -même in possessive DPs.

\footnotetext{
${ }^{21}$ For example, Eckardt (2001: 399) considers cases such as (34b) as open cases.
} 
Its specificity is that it is a type-lifted version of the identity function that can target either the possessor or the possessum.

Furthermore, based on the similarity between propre and -même, I have suggested that adnominal and adverbial uses of intensifiers should be analyzed as the same phenomenon: the core meaning of intensifiers is to involve an identity function in focus (thereby relating to contextually salient alternative functions that do not map the respective referent onto itself, but onto some other referent) which may take different semantic arguments, whether the surface syntax of the intensifier remains the same (cf. propre) or not (cf. même).

\section{References}

Bergeton, Uffe: 2004, The Independence of Binding and Intensification. Doctoral Dissertation, University of Southern California.

Charnavel, Isabelle: 2009a, 'Anaphoricity, Logophoricity and Intensification: the Puzzling Case of son propre in French', to appear in Proceedings of LSRL39.

Charnavel, Isabelle: 2009b, Linking Binding and Focus: on Intensifying son propre in French. Master Thesis, UCLA.

Eckardt, Regine: 2001, 'Reanalyzing selbst', Natural Language Semantics, 9, 4, 371-412.

Heim, Irene: 1984, 'A note on negative polarity and downward entailingness', in C. Jones and P. Sells (eds.) Proceedings of NELS 14, University of Massachusetts, Amherst.

Hole, Daniel: 2002, 'Agentive selbst in German', in Graham Katz, Sabine Reinhard, and Philip Reuter (eds.) Sinn \& Bedeutung VI, Proceedings of the Sixth Annual Meeting of the Gesellschaft für Semantik, University of Osnabrück.

Kratzer, Angelika: 1996, 'Severing the external argument from its verb', in J. Rooryck and L. Zaring (eds.) Phrase Structure and the Lexicon, 109-137, Kluwer, Dordrecht.

Moravscik, Edith: 1972, 'Some Cross-linguistic Generalizations about Intensifier Constructions', CLS 8, 271-277.

Rooth, Mats: 1985, Association with focus. Doctoral dissertation, University of Massachusetts, Amherst.

Rooth, Mats: 1992, 'A Theory of Focus Interpretation', in Natural Language Semantics, 1, 75-116.

Rullmann, Hotze: 1997, 'Even, Polarity, and Scope', in Martha Gibson, Grace Wiebe and Gary Libben (eds.) Papers in Experimental and Theoretical Linguistics, 4, 40-64, University of Alberta. 